\title{
Salary differentials according to sex in urban China
}

Foreign-invested enterprises pay men lower hourly wages than central and provincial state enterprises

Yi Chen, Sylvie Démurger et Martin Fournier

\section{(2) OpenEdition}

\section{Journals}

Édition électronique

URL : http://journals.openedition.org/chinaperspectives/2992

DOI : 10.4000/chinaperspectives.2992

ISSN : 1996-4617

Éditeur

Centre d'étude français sur la Chine contemporaine

\section{Édition imprimée}

Date de publication : 1 juillet 2004

ISSN : 2070-3449

Référence électronique

Yi Chen, Sylvie Démurger et Martin Fournier, "Salary differentials according to sex in urban China », China Perspectives [En ligne], 54 | July-August 2004, mis en ligne le 17 avril 2008, consulté le 28 octobre 2019. URL : http://journals.openedition.org/chinaperspectives/2992 ; DOI : 10.4000/ chinaperspectives.2992

Ce document a été généré automatiquement le 28 octobre 2019.

(c) All rights reserved 


\title{
Salary differentials according to sex in urban China
}

\author{
Foreign-invested enterprises pay men lower hourly wages than central
} and provincial state enterprises

\section{Yi Chen, Sylvie Démurger et Martin Fournier}

\section{NOTE DE L'ÉDITEUR}

Translated from the French original by Philip Liddell

1 Before the reforms began in the late 1970s, there was no such thing as a labour market in China ${ }^{1}$. The allocation of jobs, just as the rules governing wages in the state enterprises, were fixed by the Central Plan; and one of the key functions of the state enterprises was to provide work for the entire population of working age. The pay structure was characterised by a rigid system for determining wages and salaries; these were kept at a low level and mostly based on an egalitarian principle, promotions and wage increases being principally a function of seniority. The state enterprises were not only providers of work; they also provided a fairly complete range of social benefits (including accommodation, health care and retirement pensions) designed to make up for the low income levels. Lastly, because of the system that appointed citizens to jobs for life and because of the strict control of people's movements (within the context of registering households, hukou), the mobility of labour was extremely limited, both by sector and also geographically2.

2 The introduction of economic reforms, especially the industrial reforms from 1984 onwards, led to significant changes in the labour market. A non-state sector emerged with wider autonomy of management; and this allowed part of the labour force to be redeployed outside the state system. Thus, the non-state sector's share of employment has shown regular growth since 1978, rising from $30 \%$ in 1988 to $35 \%$ in 1995 , and accounting for about half of all urban employment by 2002. During the early stages of reform, it was mainly the collective enterprises that enabled employment to rise ${ }^{3}$. The 
private companies, with the exception of foreign capital enterprises, were subject to restrictive policies, particularly a limited access to credit and to skilled workers during the 1980s. During the 1990s, the private sector underwent rapid development and progressively acquired legitimacy, while the influence of the collectives in the economy was declining. Within the non-state sector, the collective enterprises saw their share diminish while the private sector (private enterprises, foreign-invested enterprises, personally-owned businesses) increased its share of employment from less than $5 \%$ in 1988 to nearly $15 \%$ in 1995 and to $33 \%$ by 2002 (see Table 1). This development allowed market forces to be brought into the Chinese economy, because these enterprises, operating outside the Central Plan, can make relatively independent decisions about employment policy and wage scales in relation to their essential aim of maximising profits.

Employees by enterprise ownership (\%)

\begin{tabular}{|c|c|c|c|c|c|c|c|}
\hline & $\begin{array}{l}\text { State-owned } \\
\text { enterprises }\end{array}$ & $\begin{array}{c}\text { Urban } \\
\text { collective- } \\
\text { owned units }\end{array}$ & $\begin{array}{c}\text { Limited } \\
\text { liability } \\
\text { corporations }\end{array}$ & $\begin{array}{c}\text { Share } \\
\text { holding } \\
\text { corporations }\end{array}$ & $\begin{array}{c}\text { Private } \\
\text { enterprises }\end{array}$ & $\begin{array}{c}\text { Foreign } \\
\text { invested } \\
\text { enterprises }\end{array}$ & $\begin{array}{l}\text { Individual } \\
\text { enterprises }\end{array}$ \\
\hline 1988 & 70 & 24.7 & - & - & - & 0.2 & 4.6 \\
\hline 1989 & 70.2 & 24.3 & - & - & - & 0.3 & 4.5 \\
\hline 1990 & 70.2 & 24 & - & - & 0.4 & 0.4 & 4.2 \\
\hline 1991 & 69.9 & 23.8 & - & - & 0.4 & 1 & 4.5 \\
\hline 1992 & 69.6 & 23.1 & - & - & 0.6 & 1.4 & 4.7 \\
\hline 1993 & 68.4 & 21.3 & - & 1 & 1.2 & 1.8 & 5.8 \\
\hline 1994 & 66.7 & 19.5 & - & 1.7 & 2 & 2.4 & 7.3 \\
\hline 1995 & 65 & 18.2 & - & 1.8 & 2.8 & 3 & 9 \\
\hline 1996 & 64.1 & 17.2 & - & 2.1 & 3.5 & 3.1 & 9.7 \\
\hline 1997 & 62,4 & 16.3 & - & 2.6 & 4.2 & 3.3 & 10.8 \\
\hline 1998 & 56.9 & 13.2 & 3 & 2.6 & 6.1 & 3.7 & 14.2 \\
\hline 1999 & 55 & 11.9 & 3.9 & 2.7 & 6.8 & 3.9 & 15.5 \\
\hline 2000 & 54.1 & 11 & 4.6 & 3 & 8.5 & 4.3 & 14.3 \\
\hline 2001 & 51.7 & 9.7 & 5.7 & 3.3 & 10.3 & 4.5 & 14.4 \\
\hline 2002 & 47.3 & 8.5 & 7.2 & 3.6 & 13.2 & 5 & 15 \\
\hline
\end{tabular}

NB: From 1988 onwards, "Collective Enterprises" include "Cooperative Units". Foreign invested firms include enterprises funded by entrepreneurs from Hong Kong, Macao and Taiwan. Figures do not sum up to $100 \%$ due to the existence of marginal enterprise types declared as "Joint Ownership Unit" and "Units of other types of ownership". Source: China Statistical Yearbook, tables 4-1, 1991-1996, and tables 5-1, 1997-2003.

3 At the same time, significant reforms were introduced in the state sector. Firstly, greater autonomy was given to managers in taking decisions about employment and wages. Moreover, they were allowed to keep some of the profits, and share these out among the workforce in the form of bonuses. The payment of these bonuses was aimed at increasing workers motivation and thus at improving the overall productivity of state enterprises. The amount set for the bonus was also presumed to reflect performance, that of both the enterprise and the individual ${ }^{4}$. As things turned out, because of the high cost of supervision, the bonuses were often awarded equally within the enterprises, and their impact in terms of productivity remains controversial. From 
1993 onwards, the state enterprises were also authorised to stand down their employees in a condition known as "waiting for work" (xiagang) while paying them a minimal subsistence rate. Squeezed by the inefficiency of their organisational structure and exposed to growing competition from the non-state sector, these enterprises ran quickly into difficulties, which in turn led to massive layoffs starting from the second half of the 1990s.

4 Studies of wage structures in China show that the type of ownership for the means of production is an important factor in the fixing of wages. Moreover, since mobility between firms is severely restricted, the urban labour market is very likely to be segmented according to the type of enterprise, because the methods of fixing pay in the enterprises observed vary according to their degree of openness to the mechanisms of the market ${ }^{5}$.

5 Addressing ourselves more specifically to wage differences between men and women in urban China, the impact of the reforms appears ambiguous ${ }^{6}$. From a theoretical point of view, the question is complicated by the presence of contradictory forces ${ }^{7}$. On the one hand, egalitarian Maoist ideology was aimed at reducing to a minimum any disparity in pay between men and women-this despite the inheritance of a strongly patriarchal society. Thus, the relaxation of rules governing the labour market may have revived some discriminatory tendencies. On the other hand, under the conditions of a competitive market, discrimination is a source of inefficiency; and the process of liberalisation may also have had the effect of lessening rigidity and therefore discrimination as well.

6 Just a glance at men's average incomes, compared with those of women, reveals that they are considerably better paid, whatever their occupation, qualifications or enterprise. Thus, in 1995, men were paid on average nearly $20 \%$ more than women, the gap being wider in collective enterprises and state enterprises than in foreign-invested enterprises. Bearing in mind the economic and institutional differences between enterprises, one may ask, firstly, whether the segmentation structure between men and women might vary according to the type of enterprise and, secondly, whether the discrimination against women might take different forms also according to the type of enterprise.

7 The analysis offered here lies on the intersection between the literature on the segmentation of the chinese labour market according to the type of enterprise and the work done on discrimination against women. We examine, on the one hand, the question of segmentation, highlighting the specificities of both sexes and, on the other, the question of discrimination, underlining features peculiar to the different types of enterprises. We propose to examine the various strata of the labour market, as well as their contribution to pay differentials according to sex and type of enterprise. The existence of a stratified labour market, in which wage levels are determined not only by differences in qualifications but also by different institutional arrangements, may have important implications for the allocation of work between sectors and for the distribution of incomes among wage-earners. In the case of China, some writers have suggested that the disparity in incomes in state and non-state enterprises could favour the reallocation of labour outside the state sector ${ }^{8}$. Moreover, the segmentation of the labour market between enterprises having different forms of ownership offers a possible explanation for the growth of pay inequalities observed during the reform process $^{9}$. 
The database

The data we use come from the second survey by the China Household Income Project (CHIP). This data was collected in 1996 by a team from the Institute of Economics at the Chinese Academy of Social Sciences ${ }^{10}$, and comprises detailed information relating to 6,931 households and 21,694 individuals in urban China. The survey was carried out in 11 provinces $^{11}$, only four of these being coastal provinces (Peking, Liaoning, Jiangsu and Guangdong). Given the speed of the economy's transition, to analyse the single year of 1995 might not seem, on the face of it, very pertinent. However, to our knowledge, no comparable work based on data any more recent than 1998 has been published on this subject; and the data we are using here is the only easily accessible source offering us an overall view of the question. Our results may also be interpreted as an appraisal of the Chinese labour market after ten years of reforms, enabling us to lay the foundations for an analysis of more recent developments. Indeed, while one can hardly consider that a real "labour market" existed in 1995, the remuneration structure for urban wage-earners had nevertheless been radically altered by the economic changes that had taken place since 1978. The effects of this evolution upon the segmentation of and discrimination against women are examined here.

9 The sample we are using encompasses 9,984 wage-earners. We have taken into consideration only those individuals, aged between 16 and 60, who declare that they have worked for at least a part of the year and receive payment in 1995. We consider four types of ownership of the means of production, corresponding to four categories of enterprise: state enterprises at central or provincial level, local state enterprises, urban collective enterprises and foreign-invested enterprises ${ }^{12}$. At the aggregated level, central or provincial state enterprises represent $9.3 \%$ of the total number of state enterprises, the remaining $90.7 \%$ being accounted for by local state enterprises. But the former are of far greater average size than the latter, since they employ $37.7 \%$ of the total labour force in the state sector ${ }^{13}$.

10 The total annual pay of an individual is defined here as the sum of various elements: the basic pay, bonuses, benefits (outside those paid within the context of xiagang status) and allowances (accommodation, health care, family allowances and regional allowances), extra payments (particularly overtime payments), any other income paid by the workplace, as well as the monetary equivalent of payment in kind as evaluated by those persons questioned. Further, hourly pay is defined here as total annual pay divided by the declared number of hours worked in a year. 


\begin{tabular}{|c|c|c|c|c|c|c|}
\hline & & Total & $\begin{array}{c}\text { Central } \\
\text { state-owned } \\
\text { enterprises }\end{array}$ & $\begin{array}{l}\text { Local } \\
\text { state-owned } \\
\text { enterprises }\end{array}$ & $\begin{array}{c}\text { Urban } \\
\text { collective- } \\
\text { owned units }\end{array}$ & $\begin{array}{l}\text { Foreign } \\
\text { invested } \\
\text { enterprises }\end{array}$ \\
\hline \multicolumn{2}{|l|}{$\begin{array}{l}\text { Observations } \\
\text { (\%) }\end{array}$} & $\begin{array}{l}9,984 \\
(100)\end{array}$ & $\begin{array}{l}2.653 \\
(26.5)\end{array}$ & $\begin{array}{l}5,599 \\
(56.1)\end{array}$ & $\begin{array}{l}1,602 \\
(16.1)\end{array}$ & $\begin{array}{r}130 \\
(1.3)\end{array}$ \\
\hline \multicolumn{2}{|l|}{$\operatorname{Men}(\%)$} & 52.7 & 59.9 & 53.2 & 39.0 & 54.6 \\
\hline \multirow{2}{*}{$\begin{array}{l}\text { Distribution by } \\
\text { enterprise type (\%) }\end{array}$} & Women & 100 & 22.5 & 55.5 & 20.7 & 1.3 \\
\hline & Men & 100 & 30.1 & 56.6 & 11.9 & 1.4 \\
\hline \multirow{2}{*}{$\begin{array}{l}\text { Average age } \\
\text { (years) }\end{array}$} & Women & 37.0 & 37.6 & 36.9 & 37.3 & 30.2 \\
\hline & Men & 39.6 & 40.3 & 39.5 & 38.9 & 31.9 \\
\hline \multirow{2}{*}{$\begin{array}{l}\text { Average educational } \\
\text { attainment (years) }\end{array}$} & Women & 11.2 & 11.8 & 11.5 & 9.9 & 11.2 \\
\hline & Men & 11.8 & 12.2 & 11.9 & 10.3 & 11.8 \\
\hline \multirow{2}{*}{$\begin{array}{l}\text { Communist Party } \\
\text { members }(\%)\end{array}$} & Women & 15.2 & 19.0 & 16.1 & 9.3 & 5.1 \\
\hline & Men & 33.3 & 35.8 & 36.0 & 16.2 & 12.7 \\
\hline \multirow{2}{*}{$\begin{array}{l}\text { Tertiary sector } \\
(\%)\end{array}$} & Women & 54.7 & 57.7 & 59.3 & 39.6 & 42.4 \\
\hline & Men & 50.7 & 52.2 & 54.5 & 30.4 & 35.2 \\
\hline \multirow{2}{*}{$\begin{array}{l}\text { Qualified workers } \\
(\%)\end{array}$} & Women & 63.3 & 73.4 & 65.8 & 45.9 & 57.6 \\
\hline & Men & 66.2 & 70.0 & 65.0 & 61.8 & 71.8 \\
\hline
\end{tabular}

Sources: Authors' calculations from survey data (China Household Income Project, Institute of Economics, China Academy of Social Sciences).

11 Table 2 describes the sample's characteristics, according to sex and type of enterprise. Men are over-represented in large state enterprises and women are more numerous in collective enterprises; this highlights one dimension of the pay differential between men and women: the distribution of men and women among the various types of enterprises. Indeed, while some enterprises offer higher pay than others, pay differentials caused by the segmentation of the labour market will have an impact on the difference between men and women's average pay. The men are also older, slightly better educated, far more often members of the Communist Party and less numerous in the services sectors of industry. As to the differences between types of enterprise, for the men as for the women, the average age is lower in foreign-invested enterprises; education and qualification levels are higher in large state enterprises and lower in collective enterprises; the employees of collective enterprises and foreign-invested enterprises are more heavily concentrated in the manufacturing sector. Lastly, the women are more often skilled than men in large state enterprises, and far less often in collective enterprises and foreign-invested enterprises. The differences indicated here underline the need to take account of differences in characteristics between categories of employees (sex or type of enterprise) to assess the pay differentials observed. 
In 1995 average wages for men were $20 \%$ higher than for women

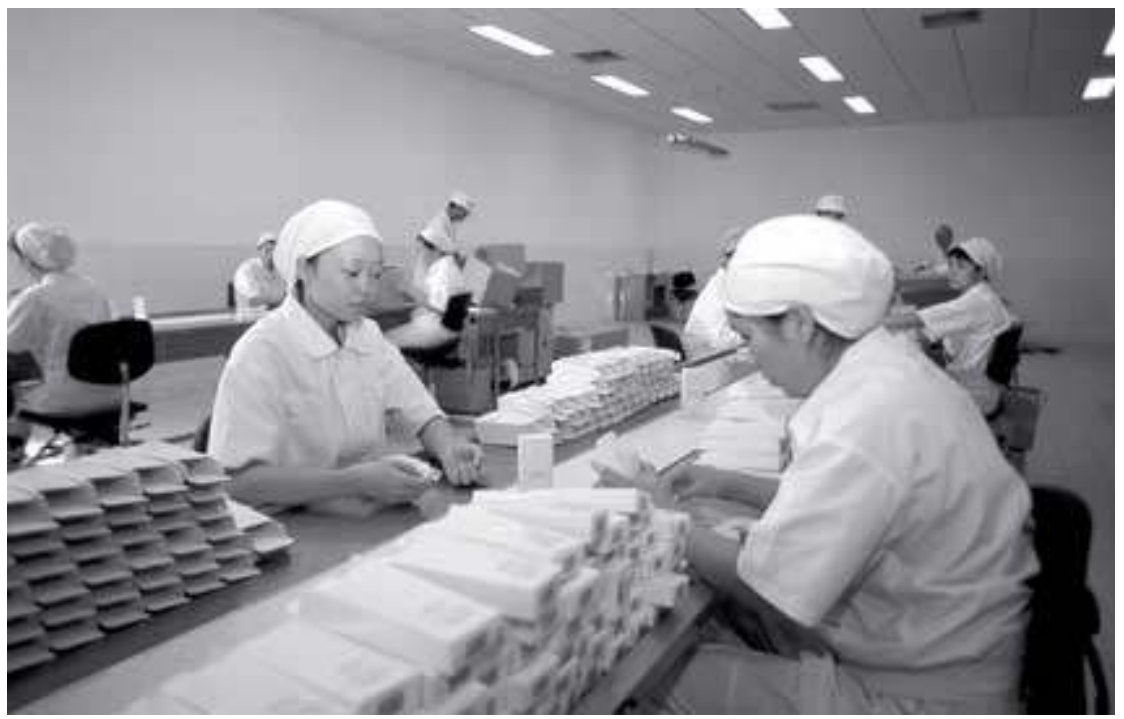

(C) Imaginechina

Pay differentials according to type of enterprise in 1995

12 As is shown in Table 3, annual pay in 1995 was highest in foreign-invested enterprises; next came the central and provincial state enterprises, followed by the local state enterprises and collective enterprises. 
Average wages and wages components by enterprise ownership and gender

\begin{tabular}{|c|c|c|c|c|c|c|c|c|c|c|}
\hline $\begin{array}{l}\text { women } \\
\text { men: }\end{array}$ & \multicolumn{2}{|c|}{ Total } & \multicolumn{2}{|c|}{$\begin{array}{l}\text { Central } \\
\text { and provincial } \\
\text { state-owned } \\
\text { enterprises }\end{array}$} & \multicolumn{2}{|c|}{$\begin{array}{l}\text { Local } \\
\text { state-owned } \\
\text { enterprises }\end{array}$} & \multicolumn{2}{|c|}{$\begin{array}{l}\text { Urban } \\
\text { collective- } \\
\text { owned units }\end{array}$} & \multicolumn{2}{|c|}{$\begin{array}{l}\text { Foreign } \\
\text { invested } \\
\text { enterprises }\end{array}$} \\
\hline Observations & 4,723 & 5,261 & 1,065 & 1,588 & 2,622 & 2,977 & 977 & 625 & 59 & 71 \\
\hline $\begin{array}{l}\text { Average annual } \\
\text { wage (yuan) }\end{array}$ & 5.628 & 6,668 & 6,469 & 7,299 & 5,684 & 6,596 & 4,482 & 5,287 & 7,639 & 7,949 \\
\hline $\begin{array}{l}\text { Base wage } \\
\text { (yuan) }\end{array}$ & 3,265 & 3921 & 3,651 & 4,252 & 3,256 & 3,779 & 2,797 & 3,502 & 5,318 & 6,671 \\
\hline (\%) & 58.0 & 58.8 & 56.4 & 58.3 & 57.3 & 57.3 & 62.4 & 66.2 & 69.6 & 83.9 \\
\hline $\begin{array}{l}\text { Bonuses } \\
\text { (yuan) }\end{array}$ & 883 & 1,048 & 976 & 1.075 & 902 & 1,116 & 730 & 764 & 1,348 & 638 \\
\hline (9) & 157 & 157 & 15.1 & 14.7 & 15.9 & 16.9 & 16.3 & 14.5 & 17.6 & 8.0 \\
\hline $\begin{array}{l}\text { Subsidies } \\
\text { (yuan) }\end{array}$ & 987 & 1,114 & 1,275 & 1,343 & 1,037 & 1,116 & 606 & 661 & 597 & 471 \\
\hline (\%) & 17.5 & 16.7 & 19.7 & 18.4 & 18.2 & 16.9 & 13.5 & 12.5 & 7.8 & 5.9 \\
\hline $\begin{array}{l}\text { Income in kind } \\
\text { (yuan) }\end{array}$ & 82 & 107 & 105 & 125 & 79 & 104 & 65 & 75 & 123 & 66 \\
\hline (\%) & 1.5 & 1.6 & 1.6 & 1.7 & 1.4 & 1.6 & 1.5 & 1.4 & 1.6 & 0.8 \\
\hline
\end{tabular}

NB: - Our sample includes wage recipients aged between 16 and 60 who declared working at least part of the year in 1995.

- Wage is defined as the sum of base wage, bonuses, allowances, subsidies, other income from work unit and income in kind.

Sources: Authors' calculations from survey data (China Household Income Project, Institute of Economics, China Academy of Social Sciences).

13 A detailed analysis of total earnings shows that benefits in addition to wages are significant among the differences between the state sector and the non-state sector. It is the state enterprises that pay out the most significant bonuses and allowances; they pay far more in allowances (covering accommodation, health care and so on) than domestic-owned or foreign-owned non-state enterprises. Thus, in 1995, allowances amounted to nearly $20 \%$ of people's earnings from state enterprises. Bonuses are an interesting measure of the difference in pay for men and women. Indeed, whereas bonus levels are the lowest for men in foreign-invested enterprises, for women they are the highest.

14 Taking into account the number of hours worked, the pay disparities alter noticeably, a fact that is rarely brought out in the literature on the labour market in China. Thus, looking at hourly pay (see Table 4), the employees of foreign-invested enterprises and central state enterprises are still the best paid, but the difference between these two categories is slight; it is the same when we compare men's pay in foreign-invested enterprises with their pay in local state enterprises ${ }^{14}$. Thus, while their total pay packet is larger, employees in foreign-invested enterprises work significantly longer hours than employees in the state sector: this sharply narrows the gap in terms of hourly pay. 
Total wages, hourly wages and working hours in 1995

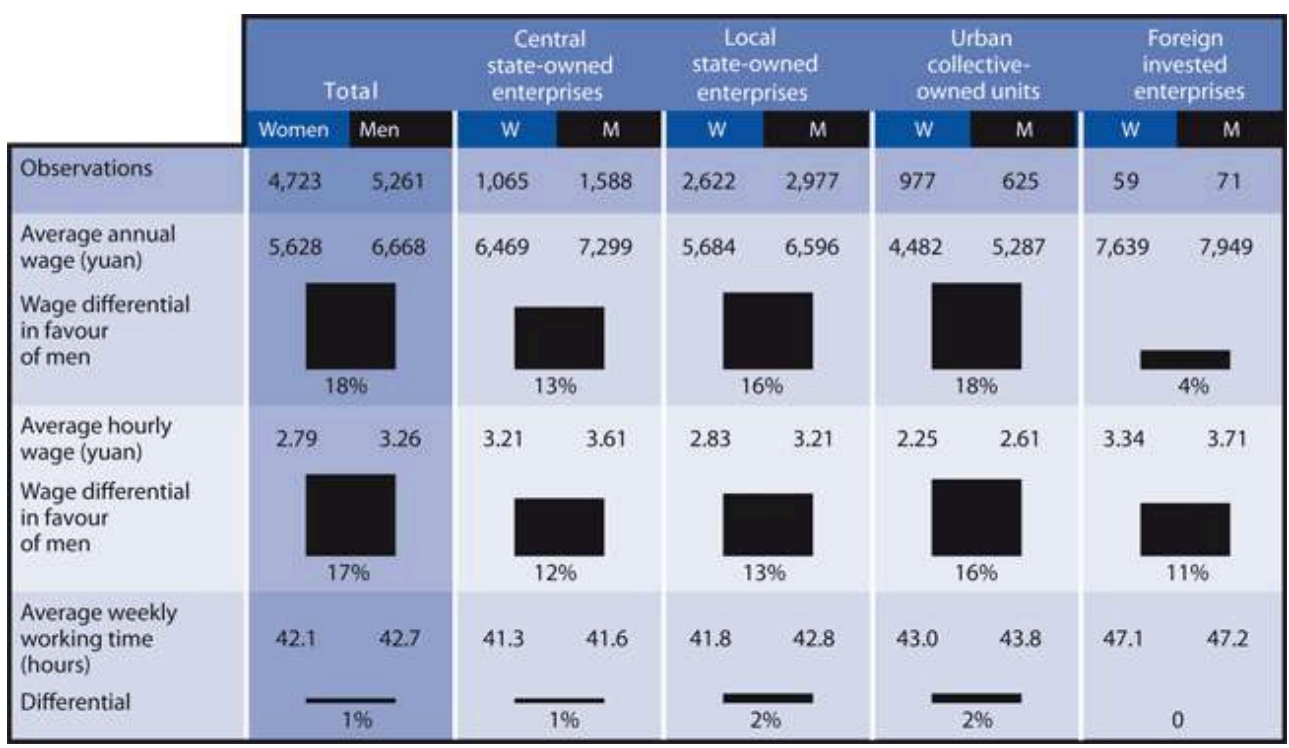

Sources: Authors' calculations from survey data (China Household Income Project, Institute of Economics, China Academy of Social Sciences).

15 Table 4 also gives information on discrimination against women in terms of average pay. The differential (overall and hourly) is greatest in the collectives, followed by local state enterprises and then by central state enterprises. The differential in average pay between men and women is still smallest in foreign-invested enterprises ${ }^{15}$. Moreover, the overall differential across the range of enterprises ( $18 \%$ for annual pay and $17 \%$ for hourly pay) is noticeably higher than all the differentials by type of enterprise: this confirms that an important aspect of the discrimination against women arises from their being over-represented in enterprises paying the lowest wages, whereas men are proportionately more numerous in the higher-paying enterprises.

Breaking down the figures

16 Our aim is to explain the observed pay gaps according to sex and type of enterprise by separating what is due to differences in the wage-earners' socio-demographic structure from what is due to the phenomena of segmentation and discrimination. The analysis technique used here allows us to calculate hypothetical wage rates corresponding to the incomes that employees of a particular type of enterprise (or of a given sex) would earn if they were subject to the pay structure of a different type of enterprise (or of the other sex $)^{16}$. Comparing the observed incomes with the incomes simulated in this way enables us then to evaluate what proportion of pay differentials can be strictly attributed to segmentation or discrimination. Thus, any difference between the observed income of employees in central state enterprises and the simulated income for the same people in the "foreign-invested enterprises model" offers us a measure of the segmentation between these two types of enterprise. In the absence of an "ownership type" effect, the income in the central state enterprises' model (observed income) ought to be identical to the income in the foreign-invested enterprises model for any given socio-demographic characteristic.

17 In addition, a potentially significant dimension of pay gaps is the number of hours worked. Between various types of enterprises and, to some extent, between men and women, there are substantial differences in working hours. Consequently, our 
statistical breakdown distinguishes three complementary sources for the observed pay differentials: the specific characteristics of the wage-earners (education, experience and qualifications) ${ }^{17}$, the number of hours worked and, lastly, the phenomena of segmentation and discrimination.

Breakdown of observed pay differences by type of enterprise

The results of our analyses are presented in Table 5 for the population as a whole. Tables 6 and 7, which present the results for the male and female populations respectively, allow us to gauge to what extent the segmentation structure by type of enterprise varies according to sex.

Decomposition of wage differentials

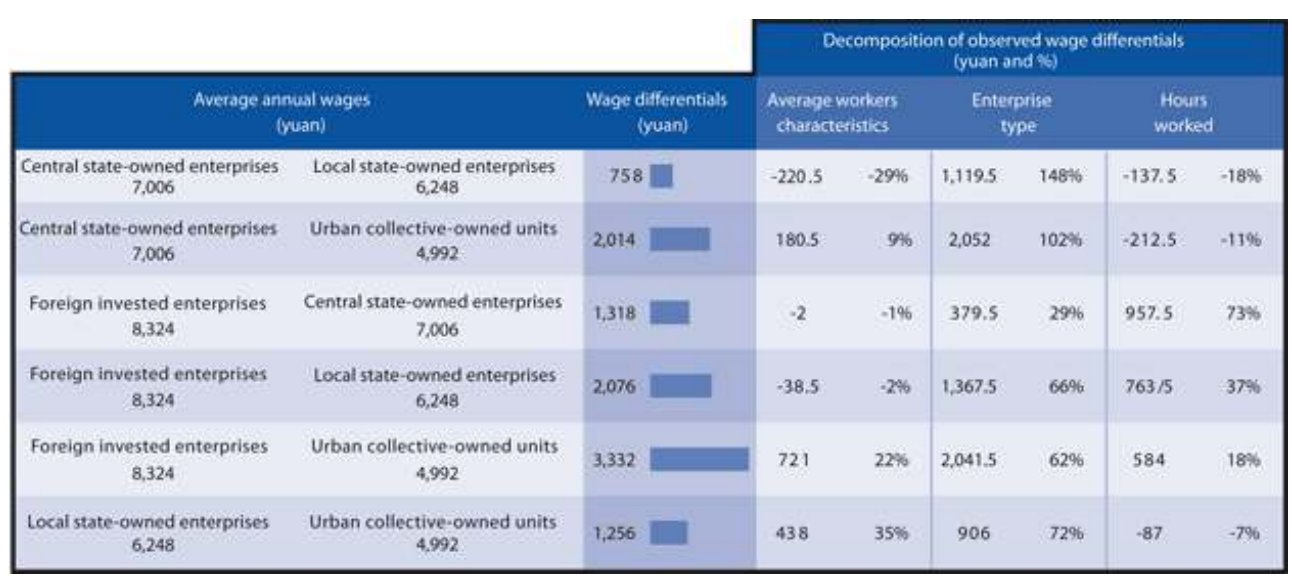

NB: Percentages in the last three columns refer to observed wage differentials

Sources: Authors' calculations from survey data (China Household Income Project, Institute of Economics, China Academy of Social Sciences).

Observed pay gaps by type of enterprise (Table 5) come from the conjunction of the "type of ownership" effect and the "number of hours worked" effect, rather than from differences in individuals' characteristics. Thus, apart from urban collective enterprises for which employees' characteristics appear markedly less good, the bulk of the observed pay disparities can be explained both by differences in working hours and by segmentation phenomena according to type of ownership. Foreign-invested enterprises and central and provincial state enterprises offer appreciably higher pay than local state enterprises, which in turn offer pay levels higher than those in collectives. This first result confirms the hypothesis that a significant proportion of the pay gaps among employees in the various types of enterprise have their origins in the stratification of the urban labour market. 


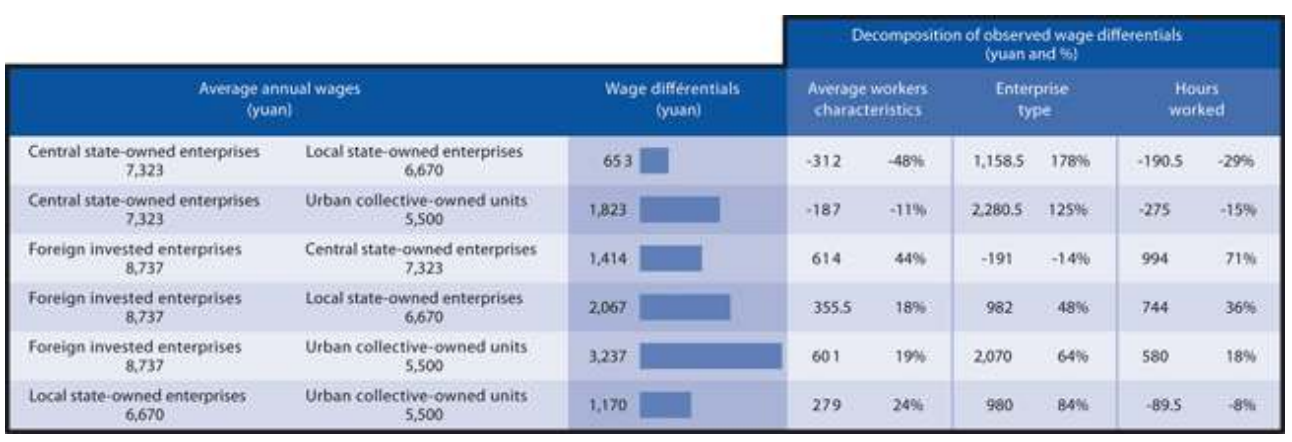

NB: Percentages in the last three columns refer to observed wage differentials.

Sources: Authors' calculations from survey data (China Household Income Project, Institute of

Economics, China Academy of Social Sciences).

20 The mechanisms at work are appreciably different according to the sex of the employees (Tables 6 and 7). In particular, the proportion of pay gaps explained by differences in employees' characteristics is notably different between men and women according to the type of enterprise. Part of the observed higher pay levels in foreigninvested enterprises compared with those in state enterprises may be attributed to superior characteristics of the male employees (the men are better qualified, on average, in foreign-invested enterprises) whereas, on the contrary, it is the women's characteristics that are superior in state enterprises (better education and qualifications, and more experience).

Decomposition of wage differentials for female workers

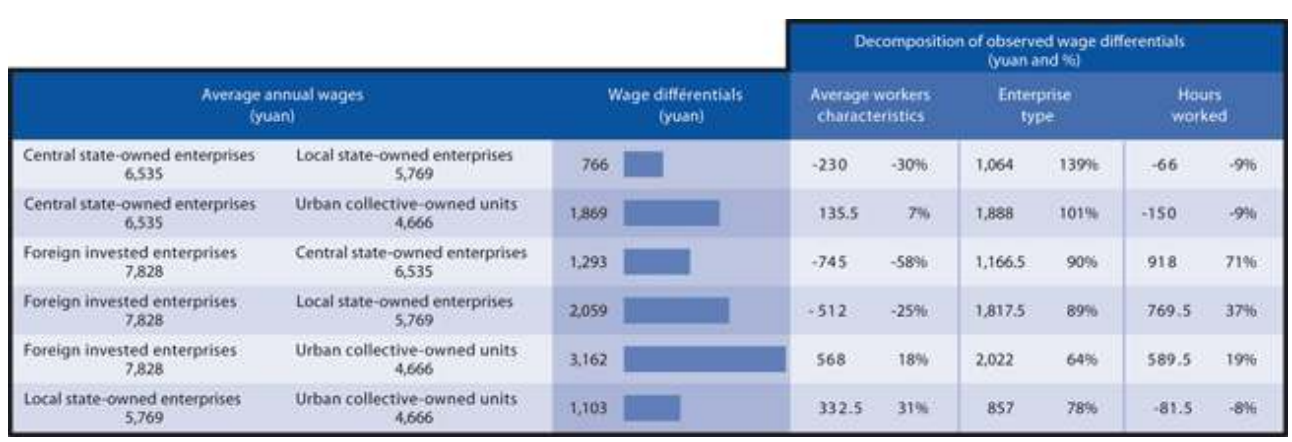

NB: Percentages in the last three columns refer to observed wage differentials.

Sources: Authors' calculations from survey data (China Household Income Project, Institute of Economics, China Academy of Social Sciences).

Similarly, the low segmentation in favour of foreign-invested enterprises as compared with central and provincial state enterprises, as observed across the whole population, arises from the conjunction of high segmentation by type of enterprise observed for women and of inverse segmentation, where foreign-invested enterprises are concerned, for men. Thus, assuming equal characteristics among employees and equal hours worked, foreign-invested enterprises pay less to men (191 yuan per year less, on average) than central and provincial state enterprises, and more (1,167 yuan per year more, on average) to women. A similar phenomenon may be observed when we look at the pay differential between foreign-invested enterprises and local state enterprises. Indeed, the high segmentation in favour of the former is clearly more significant for 
women than it is for men $(1,818$ yuan per year, on average, for women as against only 982 yuan for men).

To sum up, segmentation processes by type of enterprise are noticeably different for men and women, especially among foreign-invested enterprises and state enterprises. Men receive higher annual pay in foreign-invested enterprises despite the lower hourly pay rates, because their characteristics are superior and their working hours are longer. Women, however, receive higher hourly rates in foreign-invested enterprises: this, together with their longer working hours, makes up for their unfavourable average characteristics.

Breakdown of observed pay differences according to sex

Tables 8 and 9 analyse discrimination against women more directly. The simulations offered here attribute to men the remuneration model for women, and vice versa. The first line of Table 8 presents the aggregated results for all types of enterprise and shows a high level of discrimination against women, which explains between $40 \%$ and $50 \%$ of the observed pay differential between men and women. Assuming equal characteristics and working hours, the average annual pay for a man is higher than that for a woman by 480 yuan, which is $8 \%$ higher. About $12 \%$ of the total observed pay differential can also be explained by differences in working hours and over $40 \%$ by a combination of differences in characteristics between the sexes and their distribution among the various types of enterprises. The mere aggregation of the results of the simulations across the whole range of enterprises does not allow direct comparison of these last two effects. The final two lines of Table 8 offer an assessment of their relative significance, with the help of a re-weighting procedure. By using a common distribution by type of enterprise (that observed for men or that observed for women) we are able to monitor the impact of differences in the distribution process by type of enterprise between the two $\operatorname{sexes}^{18}$. A phenomenon of indirect discrimination as to the choice of the type of enterprise accounts for about $15 \%$ of the observed pay differential. This indirect discrimination arises from the fact that women are over-represented in the collective enterprises where pay is the lowest (assuming equal characteristics) and men are over-represented in the central state enterprises that pay higher wages. Thus, the proportion of the observed pay differential that may be directly attributed to differences in characteristics between men and women accounts only for about $25 \%$ of the total observed pay differential.

Decomposition of wage differentials between male and female workers

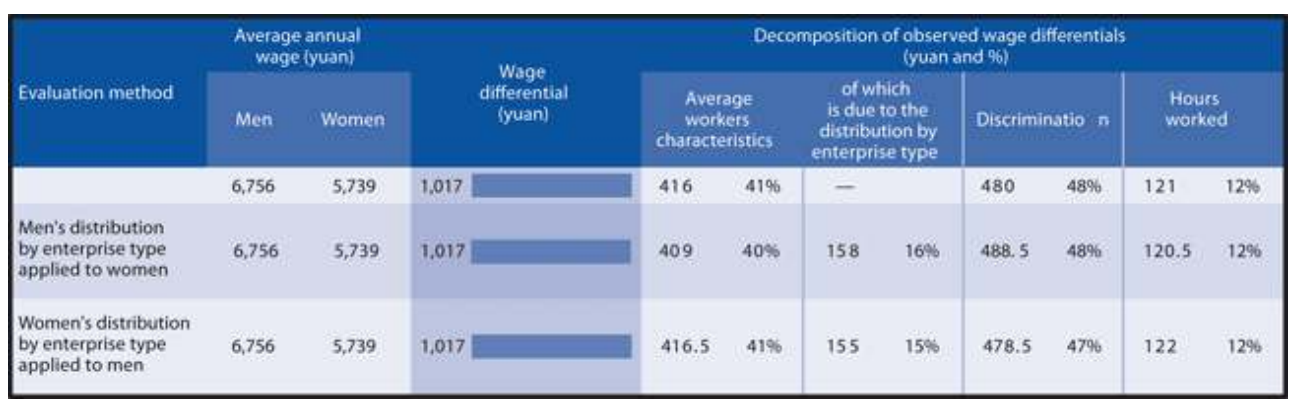

NB: Percentages in the last three columns refer to observed wage differentials.

Sources: Authors' calculations from survey data (China Household Income Project, Institute of Economics, China Academy of Social Sciences). 
Table 9 offers an analysis by type of enterprise that illustrates rather different phenomena according to the enterprises. Indeed, in absolute terms, the state enterprises show the highest level of discrimination against women. In central and provincial state enterprises, nearly $70 \%$ of the observed differential arises from the phenomenon of direct discrimination against women. By direct discrimination, we mean that part of the observed pay differential between men and women that cannot be attributed either to differences in average characteristics or to differences in working hours. The collective enterprises, where the observed pay differential is the highest, show a slightly lower absolute level of discrimination, but one that accounts nevertheless for $50 \%$ of the total. However, if we compare the difference between men's pay and women's pay due to discrimination with the average pay in each type of enterprise, the levels of discrimination appear relatively similar across the range of national enterprises. Men's pay, given equal characteristics, is between $6.5 \%$ and $8.9 \%$ higher than women's, depending on the type of enterprise.

Decomposition of wage differentials between male and female workers by enterprise ownership

\begin{tabular}{|c|c|c|c|c|c|c|c|c|c|c|}
\hline \multirow[b]{4}{*}{ Central state-owned enterprises } & \multirow{2}{*}{\multicolumn{2}{|c|}{$\begin{array}{l}\text { Average annual wages } \\
\text { (yuan) }\end{array}$}} & \multirow{3}{*}{\multicolumn{2}{|c|}{$\begin{array}{l}\text { Wage } \\
\text { differentials } \\
\text { (yuan) }\end{array}$}} & \multicolumn{6}{|c|}{$\begin{array}{l}\text { DRecomposition of observed wage differentials } \\
\text { (yuan and Sy) }\end{array}$} \\
\hline & & & & & \multirow{2}{*}{\multicolumn{2}{|c|}{$\begin{array}{l}\text { Average } \\
\text { workers } \\
\text { characteristics }\end{array}$}} & \multirow{2}{*}{\multicolumn{2}{|c|}{ Discriminatio $\mathrm{n}$}} & \multirow{2}{*}{\multicolumn{2}{|c|}{$\begin{array}{l}\text { Hours } \\
\text { worked }\end{array}$}} \\
\hline & \multirow{2}{*}{$\begin{array}{l}\text { Men } \\
7,323\end{array}$} & \multirow{2}{*}{$\begin{array}{c}\text { Women } \\
6,535\end{array}$} & & & & & & & & \\
\hline & & & 788 & & 194.5 & $25 \%$ & 518 & $66 \%$ & 74.5 & $10 \%$ \\
\hline Local state-owned enterprises & 6,670 & 5,769 & 901 & & 243.5 & 2796 & 508.5 & 5796 & 150.5 & $17 \%$ \\
\hline Urban collective-owned units & 5,500 & 4,666 & 834 & & 333 & $40 \%$ & 401 & $48 \%$ & 99.5 & $12 \%$ \\
\hline Foreign invested enterprises & 8.737 & 7,828 & 909 & & 1.066 & $117 \%$ & -263 & $-29 \%$ & 73 & $8 \%$ \\
\hline
\end{tabular}

NB: Percentages in the last three columns refer to observed wage differentials.

Sources: Authors' calculations from survey data (China Household Income Project, Institute of Economics, China Academy of Social Sciences).

When we look at foreign-invested enterprises, we find a significant difference. Indeed, our results do not support the hypothesis of discrimination against women in these enterprises and even suggest some possible discrimination against men.

Similarly, a relatively low proportion of the observed pay differential may be attributed to differences in characteristics in state enterprises, while this dimension accounts for nearly all the observed difference in foreign-invested enterprises. Lastly, as at the aggregated level, differences in working hours explain only about $10 \%$ of the observed differential, with the exception of local state enterprises where they account for nearly $20 \%$.

27 To sum up, our results show a clear opposition between the national enterprises and the foreign-invested enterprises. In the former, there is marked discrimination against women; and this, combined with differences in average characteristics and working hours, causes a large pay differential between men and women. In the latter, the only causes for the pay differential between men and women are the differences in characteristics and in working hours; and discrimination phenomena play no significant role.

The stratification of the Chinese labour market by type of enterprise is quite different for men than for women. For women, segmentation favours foreign-invested enterprises rather than state enterprises, while for men the foreign-invested enterprises offer lower hourly rates (assuming equal characteristics) than the central state enterprises. While male employees in the foreign-invested enterprises earn 
higher yearly pay than those in state enterprises, this is due only to the combination of significantly longer working hours and better average characteristics. Conversely, the average characteristics of women employed in foreign-invested enterprises are less favourable than those working in the big state enterprises; their annual earnings are higher thanks partly to significantly longer working hours and partly to the fact that the foreign-invested enterprises pay them (assuming equal characteristics) higher hourly wages.

29 Turning now to discrimination against women in each category of enterprise, our results show two main features. On the one hand, men are over-represented in central state enterprises while women are over-represented in collective enterprises. The segmentation of the labour market and the differences in distribution among enterprises between men and women lead to a primary form of discrimination against women. Indeed, the central state enterprises pay more (assuming equal characteristics) while the collective enterprises pay less. Our results put the contribution of this form of discrimination at $15 \%$ of the observed pay differential between men and women. On the other hand, there are profound differences between the national enterprises and the foreign-invested enterprises. In the national enterprises, women are paid (all other things being equal) from $6.5 \%$ to $8.9 \%$ less than men. By contrast, our results do not support the hypothesis of discrimination against women in foreign-invested enterprises and seem even to suggest the possibility of discrimination against men.

The level of discrimination is thus higher in the national enterprises than in the foreign-invested enterprises: this seems to support the hypothesis that the search for efficiency in foreign-invested firms, because they are more subject to market mechanisms, tends to encourage flexibility and lower discrimination. Moreover, indirect discrimination resulting from the distribution of men and women among the various types of enterprise accounts for a significant proportion of the pay differential.

31 The analysis of segmentation by sex reveals a second mechanism playing a central role in the observed differences between enterprises. The absence of discrimination against women in foreign-invested enterprises also stems from the fact that these enterprises offer higher hourly rates to women, and lower rates to men. This observation reveals the presence of different influences on the labour market for men than on that for women. One central difference between different categories of enterprises is the number of hours worked, far more in the foreign-invested enterprises than in the state enterprises. This difference is caused by a combination of two phenomena: on the one hand, foreign-invested enterprises require a greater investment of time from their employees and, on the other hand, they offer greater flexibility in terms of overtime. The chance of earning higher overall pay is a determining factor for men, who are ready to accept in return a lower hourly rate. Conversely, the long hours worked in foreign-invested enterprises seem to be a strong disincentive for women. This leads enterprises to offer them higher hourly rates of pay, particularly in the form of bonuses and payments in kind. The segmentation structure of the labour market seems to be the key element in explaining why discrimination against women is low in the foreigninvested companies.

Since 1995, the rapid development of the private sector has certainly had significant effects in terms of segmentation and discrimination. Access to the results of similar studies over more recent periods will surely help us to assess the changes now taking 
place within the labour market and to understand how they will affect the place of women in Chinese industry and society.

\section{NOTES}

1. The authors are grateful to Li Shi (Institute of Economics, Chinese Academy of Social Sciences, Peking) for granting them access to the household survey data used in this article.

2. See Xin Meng, Labour Market Reform in China, Cambridge, New York, Cambridge University Press, 2000 (Chapter 2), for a detailed description of the system for fixing wages and salaries before the reforms were introduced.

3. Organisation for Economic Cooperation and Development (OECD), China in the World Economy: The Domestic Policy Challenges, Paris, OECD, 2002.

4. See David P. Coady and Limin Wang, "Equity, efficiency, and labor-market reforms in urban China: the impact of bonus wages on the distribution of earnings", China Economic Review, 11(3), 2000, pp. 213-231; and Meng Xin, op. cit.

5. See Xiaoyuan Dong and Paul Bowles, "Segmentation and discrimination in China's emerging industrial labor market”, China Economic Review, 13(2-3), 2002, pp. 170-196; and Yaohui Zhao, "Earnings differentials between state and non-state enterprises in urban China", Pacific Economic Review, 7(1), 2002, pp. 181-197.

6. Margaret Maurer-Fazio and James W. Hughes, "The Effects of Market Liberalization on the Relative Earnings of Chinese Women", Journal of Comparative Economics, 30(4), 2002, pp. 709-731; Pak-Wai Liu, Xin Meng and Junsen Zhang, "Sectoral gender wage differentials and discrimination in the transitional Chinese economy", Journal of Population Economics, 13(2), pp. 331-352, 2000; Björn Gustafsson and Li Shi, "Economic transformation and the gender earnings gap in urban China", Journal of Population Economics, 13(2), 2000, pp. 305-329.

7. Liu et al. (2000), op. cit.

8. Yaohui Zhao, op. cit.

9. John Knight and Lina Song, "Increasing Urban Wage Inequality in China: Extent, Elements and Evaluation", Economics of Transition, 11(4), 2003, pp. 597-619.

10. Carl Riskin, Zhao Renwei and Li Shi, China's Retreat from Equality: Income Distribution and Economic Transition, London, M E Sharpe, 2001.

11. The sample covers the following provinces and municipalities: Peking, Shanxi, Liaoning, Jiangsu, Anhui, Henan, Guangdong, Yunnan, Sichuan, Gansu and Hubei.

12. The data used take in also a fifth category, which includes private and individuallyowned enterprises. However, the small number of observations on wage-earners in these enterprises as well as the high heterogeneousness of this category (which includes little doorstep businesses as well as industrial enterprises) does not allow us to introduce it into our statistical analysis.

13. Source: China Labour Statistical Yearbook, 1995.

14. These differences are not statistically significant: one cannot exclude the possibility that an observed difference might arise merely from the sampling process. 
15. This difference is not statistically significant (cf. the preceding note).

16. The method used here is in line with statistical analysis in the work of Ronald Oaxaca, "Male-Female Wage Differentials in Urban Labor Markets", International Economic Review, 14, 1973, pp. 693-709; and of Alan S. Blinder, "Wage Discrimination: Reduced Form and Structural Estimates", Journal of Human Resources, 8(4), 1973, pp. 436-455. The statistical method proposed here is taken from micro-simulations carried out on the basis of econometric estimates of pay functions listed by type of enterprise and by sex. The technical details about how the method is applied are set out in Yi Chen, Sylvie Démurger and Martin Fournier, "Wage Differentials and Ownership Structure in Chinese Enterprises”, HIEBS Working Paper No. 1076, 2004.

17. Part of the average pay gap between men and women may arise from the fact that men are, on average, better educated, have accumulated more years of work experience and work more often in skilled jobs.

18. Thus, the second line of Table 8 corresponds to a comparison between the observed masculine population and a counterfactual female population, in which the women are distributed among the various types of enterprise in the same relative numbers as men. The last column of Table 8 assesses the specific impact of differences in terms of distribution between types of enterprise upon the average pay gap. 